\title{
THE CURRENT STATUS OF PHYSICOCHEMICAL PARAMETERS AND WATER QUALITY OF SUNDARIJAL RESERVOIR
}

\author{
Ram Prasad Dhungana \\ Department of Science and Humanities, Khwopa Engineering College, Libali-8 Bhaktapur, Nepal
}

\begin{abstract}
Physico-chemical parameters and bacteriological characteristics of water were studied in sample collected from Sundarijal reservoir in January 2018. The present sanitary condition and human activities near the water bodies were also observed. It has been found that the physico-chemical characters were within the standard of World Health Organization (WHO) and National Drinking Water Quality Standards (NDWQS) for drinking water though the public awareness and proper management of watershed and reservoir premises were lacking. However, the coliform bacteria were high and water was not safe to consume without intense treatments with disinfectants.
\end{abstract}

Keywords: NTA, Sundarijal reservoir, AAS, NDWQS

\section{Introduction}

The river water pollution due to heavy metals is one of the major concerns in most of the metropolitan cities of developing countries. The toxic heavy metals entering the water environment may lead to bioaccumulation and bio magnifications. They are not readily degradable in nature and their accumulation in the animal as well as human bodies causes abiding threat to human and animal health.

Although cholera outbreak has already been reported in the Kathmandu valley due to the contaminated water, the authorities do not seem to be mindful about the proper waste management in the reservoir site. However locals have demanded with the authority concerned to pay due attention towards the increasing pollution in the water source at sundarijal (Bhattrai et al., 2008).

The use of detergent imparts harmful effect in the quality of river water. Some detergent sample contain Nitrilotriacetic acid (NTA). NTA is used in laundry detergents as a "builder" to replace

\footnotetext{
*Corresponding author: Ram Prasad Dhungana

Department of Science and Humanities, Khwopa Engineering

College, Libali-8 Bhaktapur, Nepal

Email: rp.dhungana@gmail.com

(Received: $7^{\text {th }}$ Feb 2019 Accepted: $7^{\text {th }}$ April 2019 )
}

phosphates because of its ability to chelate calcium and magnesium ions (WHO, 1996).

NTA can cause eye, skin, and respiratory tract irritation; and can cause kidney and bladder damage. The compound is anticipated to have the potential to cause human cancer (Wikipedia, March 2018).

The sundarijal drinking water reservoir was chosen for this study because this is one of major drinking water supply system in the Kathmandu valley providing more than $45 \%$ of present supply. It consist of two subsystem one constructed in 1966 and the other constructed in 1994.The reservoir collects the river water from three tributaries Bagmati, Shyalmati and Nagmati. The main objective of the research is to assess water quality of sundarijal reservoir. The present study is specified to measure physico-chemical parameters, heavy metals and bacteriological contamination in water. The findings are important not only for knowing the present status of water quality but also for proper management and making conservation policies to preserve pioneer reservoir of the valley.

The feeding streams of reservoir are Bagmati, Nagmati and Shyalmati, which have different 
catchment areas. The catchments of Bagmati are Bagdwar area and adjacent villages Okhreni, Chlilaune and Kune gaun, the catchments of Nagmati are Mulkharka and the adjacent forests whereas the catchment of Shyalmati have forests only and not the settlement areas.The people living in villages mentioned above are unhygienic and they seemed to be unaware about the effects of water pollution (Bhattrai et al., 2008).

There are more than 50 elements that can be categorized as heavy metals, 17 of which are considered to be very toxic and relatively accessible (Mohod, et al., 2013).Heavy metal can cause severe health effects depending on the type and concentration of the metal ingested (Adepoju-Bello and Alabi, 2005)

Although Iron and Manganese are essential nutrients, when present in high concentrations in drinking water they have been found to be associated with various health issues (Copper, I. O. M.,2001).These findings suggest that high levels of manganese and iron in drinking water are associated with a reduction in birth weight in term-born infants (Grazuleviciene1 et al., 2008).The exposure to manganese results in a decrease in fetal weight and retardation of the development of the bones and internal organs (ATSDR, 2002). Manganese also caused DNA damage and chromosomal deviations and was toxic to the embryo and fetus (Gerber et al., 2002).Epidemiological studies of inhabitants exposed to manganese shown a neurotoxic effect (Mergler et al., 1999) and Parkinson-like syndrome (Dobson et al., 2004).

Iron is a vital nutrient for most living organisms because it is a constituent or cofactor of many critical proteins and enzymes (Fine, 2000).Iron toxicity is generated by the formation of free radicals (Ryan et al.,1992, McCord,1998) .Free radicals are produced when free iron reacts with superoxide $\left(\mathrm{O}_{2}\right)$ and hydrogen peroxide $\left(\mathrm{H}_{2} \mathrm{O}_{2}\right)$ which are produced in the cellular process.

$$
\begin{aligned}
& \mathrm{Fe}^{3+}+\mathrm{O}_{2} \rightarrow \mathrm{Fe}^{2+}+\mathrm{O}_{2} \\
& \mathrm{Fe}^{2+}+\mathrm{H}_{2} \mathrm{O}_{2} \rightarrow \mathrm{Fe}^{3+}+\mathrm{OH} .+\mathrm{OH} \\
& \mathrm{O}_{2 .}+\mathrm{H}_{2} \mathrm{O}_{2} \rightarrow \mathrm{O}_{2}+\mathrm{OH} .+\mathrm{OH}
\end{aligned}
$$

The hydroxyl radical ( $\mathrm{OH}$.) formed through this reaction can depolymerize polysaccharides, cause DNA strand breaks, inactivate enzymes, and initiate lipid peroxidation, which is a self-amplifying process that is particularly damaging to cellular and subcellular membranes (Ryan et al.,1992, McCord ,1998).When lysosomal membranes are destroyed, proteolytic enzymes are released inside the cell, causing further cell damage. If the damage is irreparable, it can also lead to cell death (Hershko et al., 1998).

Lead is a commutative poison and a possible human carcinogen (Bakare-Odunola, 2005). In addition, Lead may cause the development of autoimmunity in which a person's immune system attacks its own cells. This can lead to joint diseases and ailment of the kidneys, circulatory system and neurons. At higher concentrations, Lead can cause irreversible brain damage (Orosun et al., 2016).

Chromium(III) is an vital nutrient in humans and is often added to vitamins in dietary supplement.It has relatively low toxicity and would be a concern in drinking water only at very high concentration (American Water Works Association, 2013).Chromium(VI) is identified as a human carcinogen. California Environmental Protection Agency's Office of Environmental Health Hazard Assessment (OEHHA) analyzed data collected from China (Beaumont et al., 2008).The survey found that the increased rates of stomach cancer in people who were probably exposed to very high levels of chromium(VI) in drinking water (OEHHA, 2010). However, exposure to chromium(VI) compounds from breathing dust or fumes is considered to have a much higher risk than exposure from drinking water (OEHHA, 2010).

Copper is a vital trace minerals that is extremely important for physical and mental health and it is not poisonous in metallic form but some of its salts are poisonous (Ashish, et al.,2013).Copper is a powerful inhibitor of enzymes and cofactor for a number of enzymes (Ashish, et al.,2013).However, in the case of high amount ingestion and unbalance utilization, it can be extremely toxic (Saurav et al.,2007). The circulation and proper use of copper 
in the body needs good functioning of the liver, gall bladder and adrenal glands. If any of those organs are impaired, the body cannot properly excrete and utilize copper. Initially, the copper will accumulates in the liver, further impairing its ability to excrete copper (Goeringa et al., 2007). As copper retention rises, it will accumulate in the brain, the joints and the lungs, badly affecting the structure and function of the tissues. Copper is a powerful oxidant producing inflammation and free radical injury to the tissues.

Zinc is an essential nutrient for body growth and development; however drinking water containing high levels of Zinc can lead to stomach cramps, nausea and vomiting (water, H.D.Z.G.I., 2009).Water containing zinc at concentrations in the range 3-5 $\mathrm{mgL}^{-1}$ also tends to appear opalescent and develops a greasy film when boiled (WHO, 2009).

Zinc can be introduced naturally into water by erosion of minerals from rocks and soil. River water usually makes a negligible contribution to Zinc intake because Zinc ores are only slightly soluble in water. The principal Zinc ores are sulfides, such as sphalerite and wurzite (Elinder et al., 1986).High concentrations of Zinc occur as a result of artificial pathways such as corrosion of pipings and fittings (Gillies et al., 1982). Most Zinc is introduced into water by non-natural sources such as galvanized metal pipes, well cribbings coated with Zinc or by burning of waste materials. Zinc is also used in some fertilizers that may leach into groundwater.

\section{Materials and Methods}

\subsection{Sample collection and laboratory analysis}

Water sample was collected in sterilized bottles from sundarijal reservoir at 2 PM on 30 January 2018. The physical parameters such as Temperature, TDS, EC and $\mathrm{pH}$ were analyzed immediately after sample collection.

The estimation of alkalinity and hardness were done in the chemistry laboratory of Khwopa Engineering College, Bhaktapur. The samples were stored in the plastic bottle at cold temperature (about $4^{0} \mathrm{C}$ ) before analysis.

The other chemical parameters such as Biological Oxygen Demand (BOD), Dissolved Oxygen (DO),
Chemical Oxygen Demand (COD), Nitrogen (N), Phosphorus (P),Total Coliform (TC), Faecal Coliform (FC ) and heavy metals such as Iron (Fe), Manganese (Mn), Zinc ( $\mathrm{Zn})$, Lead ( $\mathrm{Pb})$, Chromium $(\mathrm{Cr})$ and Cupper $(\mathrm{Cu})$ of water sample were analyzed in the laboratory of Water Engineering and Training Centers (P.) Ltd., Kathmandu.Table:1 shows the parameters to be tested and method used to analyze water sample.

Table 1: Methods used for the analysis of various physico-chemical parameters.

\begin{tabular}{|l|l|l|l|}
\hline $\mathbf{S}$ & Parameters & Units & Method used \\
\hline 1 & Temperature & ${ }^{0} \mathrm{C}$ & Thermometric \\
\hline 2 & TDS & $\mathrm{mg} \mathrm{L}^{-1}$ & Conductivity meter \\
\hline 3 & EC & $\mu \mathrm{cm}^{-1}$ & Conductivity meter \\
\hline 4 & $\mathrm{pH}$ & & $\mathrm{pH}$ metry \\
\hline 5 & Alkalinity & $\mathrm{mg} \mathrm{L}^{-1}$ & Titrometric (std HCl used) \\
\hline 6 & Hardness & $\mathrm{mg} \mathrm{L}^{-1}$ & $\begin{array}{l}\text { Titrometric (std EDTA } \\
\text { used) }\end{array}$ \\
\hline 7 & BOD & $\mathrm{mg} \mathrm{L}^{-1}$ & Wrinkler's method \\
\hline 8 & COD & $\mathrm{mg} \mathrm{L}^{-1}$ & Redox titrometric \\
\hline 9 & DO & $\mathrm{mg} \mathrm{L}^{-1}$ & Wrinkler's method \\
\hline 10 & Nitrogen & $\mathrm{mg} \mathrm{L}^{-1}$ & Micro-kjeldahal method \\
\hline 11 & Phosphorus & $\mathrm{mg} \mathrm{L}^{-1}$ & Spectrophotometric \\
\hline 12 & TC & $\mathrm{CFU}^{-100 m l}$ & Membrane filtration \\
\hline 13 & FC & $\mathrm{CFU}^{-100 m l}$ & Membrane filtration \\
\hline 14 & Heavy metals & $\mathrm{mg} \mathrm{L}^{-1}$ & AAS \\
\hline
\end{tabular}

\subsection{Methods used for estimation of various} physico-chemical parameters

EC and TDS were measured by conductivity meter (model no.YK-2005WA); accuracy $\pm(2 \%$ F.S. $+1 d)$ .Dissolved oxygen $\left(\mathrm{mgL}^{-1}\right)$ by Winkler's method; total nitrogen by micro-Kjeldahl method; and phosphorus by spectrophotometric method. All these methods have been described in the standard procedure of American Public Health Association (APHA) 1992. Heavy metals ( $\mathrm{Fe}, \mathrm{Mn}, \mathrm{Cr}, \mathrm{Cu}, \mathrm{Zn}$ and $\mathrm{Pb}$ ) concentrations were directly measured in the Atomic Absorption Spectrophotometer (AAS); model no.240FS AA of company named Agilent Technologies. Where a sample was aspirated into a flame and atomized. Amount of specific monochromatic light absorbed by the atomized element was measured which was calibrated to give the concentration of the element directly. The detection limit for the determination of zinc by the 
direct air-acetylene flame method is $50 \mu \mathrm{g} / \mathrm{litre}$ (ISO,1986). Low concentrations can be measured by chelating zinc with ammonium pyrrolidine dithiocarbamate and extracting it with methyl isobutyl ketone (detection limit $0.5-1 \mu \mathrm{g} /$ litre) (zur Wasser, 1989).

\subsection{Bacterial Analysis}

Membrane Filtration method was used to determine the total coliform (TC) and faecal coliform (FC). Similarly APHA standard procedure was utilized for culture and enumeration. Accordingly, the sample was analyzed after 2-3 hours of sample collection. For total coliforms, Whatman sterile filter paper of pore size $0.45 \mu \mathrm{m}$ was used to filter $100 \mathrm{ml}$ water sample. Then, the filter paper was placed on sterilized plate containing $2 \mathrm{ml}$ M-ENDO agar as media spreaded on mediapad (Whatman). The prepared sample was incubated at $37 \pm 0.5^{\circ} \mathrm{C}$ for 48 hours. For faecal coliform, the sterile filter paper of pore size $0.45 \mu \mathrm{m}$ was used to filter $100 \mathrm{ml}$ of the sample. Then, the filter paper was kept on sterilized plate containing $2 \mathrm{ml}$ M-ENDO agar as media spreaded on media pad. The prepared sample was incubated at $44.5 \pm 0.5^{\circ} \mathrm{C}$ for 24 hours. Each negative plate was further incubated for 48 hours. The confirmatory tests were performed for the sample following the presumptive test to find total coliform.

\section{Result and Discussion}

In the present study the recent findings were compared with past result (Research done by Bhattrai et al., 2008) of the water quality of the same reservoir. The parameters such as TDS, COD were found lower but $\mathrm{Zn}, \mathrm{N}$, Hardness and bacterial contamination were found higher than the previous record. Table 2: Shows NDWQS, past (2008) and present (2018) findings of water analysis, sample taken from sundarijal reservoir.

About 15\% of household near the reservoir depends on the streams for drinking water and only about $30 \%$ of the household used septic tank in their toilet. (Bhattrai et al., 2008).According to the same authors the villages near the catchment (about 2 kilometers from reservoir) were seem to be unhygienic and unconscious about water pollution. The unsanitary condition near the catchment areas could be responsible for bacterial contamination and high TC and FC count in the water bodies of sundarijal area (Shrestha et al., 1996 and ENPHO 1997). In the study TC and FC count were $200 / 100 \mathrm{ml}$ and $60 / 100 \mathrm{ml}$ respectively. Both of the parameters were higher than the previous record of the same reservoir.

Table 2: NDWQS, past (2008) and present (2018) result of physicochemical parameters of water sample taken from sundarijal reservoir.

\begin{tabular}{|c|c|c|c|c|}
\hline SN & Parameters & NDWQS & 2008 & 2018 \\
\hline 1 & Temperature (0C) & - & 11 & 8.2 \\
\hline 2 & $\operatorname{TDS}\left(\mathrm{mgL}^{-1}\right)$ & 1000 & 40 & 22.4 \\
\hline 3 & $\mathrm{EC}(\mu \mathrm{s} / \mathrm{cm})$ & 1500 & 15.48 & 33.2 \\
\hline 4 & $\mathrm{PH}$ & $6.5-8.5$ & 5.9 & 7.27 \\
\hline 5 & Alkalinity $\left(\mathrm{mgL}^{-1}\right)$ & - & 50 & 24.5 \\
\hline 6 & Hardness & 500 & 7 & 20 \\
\hline 7 & $\mathrm{BOD}\left(\mathrm{mgL}^{-1}\right)$ & - & - & 2 \\
\hline 8 & $\mathrm{DO}\left(\mathrm{mgL}^{-1}\right)$ & - & 8.4 & 7.9 \\
\hline 9 & $\operatorname{COD}\left(\mathrm{mgL}^{-1}\right)$ & - & 11 & 5.5 \\
\hline 10 & Nitrogen $\left(\mathrm{mgL}^{-1}\right)$ & - & 0 & 7 \\
\hline 11 & Phosphorus $\left(\mathrm{mgL}^{-1}\right)$ & - & 0 & 0.04 \\
\hline 12 & TC $($ colonies $/ 100 \mathrm{ml})$ & Nil & 112 & 200 \\
\hline 13 & $\mathrm{FC}$ (colonies/100ml) & Nil & 58 & 60 \\
\hline 14 & Iron $\left(\mathrm{mgL}^{-1}\right)$ & 0.3 & 0.04 & 0.05 \\
\hline 15 & Manganese $\left(\mathrm{mgL}^{-1}\right)$ & 0.2 & $<.01$ & $<.01$ \\
\hline 16 & Zinc $\left(\mathrm{mgL}^{-1}\right)$ & 3 & $<.01$ & 0.32 \\
\hline 17 & Lead $\left(\mathrm{mgL}^{-1}\right)$ & 0.01 & $<.01$ & $<.01$ \\
\hline 18 & Chromium $\left(\mathrm{mgL}^{-1}\right)$ & 0.05 & $<.01$ & $<.05$ \\
\hline 19 & Copper $\left(\mathrm{mgL}^{-1}\right)$ & 1 & $<.01$ & $<.01$ \\
\hline
\end{tabular}

The water temperature of the reservoir was highest during mid-monsoon and lowest during winter (Paudyal, 2001 and ENPHO, 1997).The change in temperature of water body was found to be related with corresponding change in atmospheric temperature (Kaudanagar et al., 1996). Water temperature of the reservoir was low $\left(8.2^{\circ} \mathrm{C}\right)$ at the time of sample collection.

The factors such as temperature, dissolved $\mathrm{CO}_{2}$, liberation of ions and buffering capacity of water affects the seasonal change in $\mathrm{pH}$ of water (Agrawal, 1999).The $\mathrm{pH}$ measured in present study was 7.27, similar to previous reports for Sundarijal area ((Bhattrai et al., 2008)). 
The Total Dissolved Solid of the reservoir water was highest in pre-monsoon and lowest in mid monsoon (Bhattrai et al., 2008). The seasonal change in temperature affects the amount of dissolve solutes, which could be high in monsoon due to dilution, increase in water volume in the reservoir. The TDS measurement in present study was $22.4 \mathrm{mgL}^{-1}$ far below the permissible level of drinking water standard of WHO (1000mgL-1).A higher conductivity indicates the presence of higher amount of dissolved salts as well as plants nutrients in water.

The low conductivity may be due to low inputs of ions at low temperature. The water conductivity measured in our sample was (33.2 micro Siemen per $\mathrm{cm})$ lower than in pristine stream that normally ranged from 35 to 60 micro Siemen per $\mathrm{cm}$ (ENPHO, 1997). The value found in present study report was higher than previous report of the same reservoir .

The high conductivity could be possible because most of the dissolved substances nearly ionize and raise conductivity as expected.

The alkalinity was mainly due to water soluble bicarbonates salts whereas the carbonates salts were not in predictable amount because there would be practically no carbonates in water with $\mathrm{pH}$ from 4.5 to 8.3 (Jhingran, 1975).The total alkalinity measured in our water sample was $24.5 \mathrm{mgL}^{-1}$ lower than the previous report; $50 \mathrm{mgL}^{-1}$ (Bhattrai et al., 2008). The lower alkalinity indicates that the contamination of $\mathrm{HCO}_{3}{ }^{-}$and $\mathrm{OH}$ - ions from minerals and rocks has decreased over the time.

DO refer to the level of free or non-compound oxygen present in water. It is most important among all of them; it is not only required by most of the aquatic organism but also an important indicator of water quality. DO come from the atmosphere and from photosynthesis by aquatic plants, and is depleted through chemical oxidation and respiration by aquatic animals and microorganisms, especially during the decomposition of plant biomass and other organic matter. The amount of oxygen that dissolves in water can vary in daily and seasonal patterns, and decreases with higher temperature, salinity, and elevation.

In the study, DO level was $7.9 \mathrm{mgL}^{-1}$. The difference in the concentration of DO in water sample of a particular area might be explained by a combined effect of temperature, Photosynthesis, respiration, organic waste, aeration and sedimentation concentration (Badge et al., 1985) The maximum solubility of oxygen in water at standard pressure (1 atm) ranges from about $15 \mathrm{mgL}^{-1}$ at $0^{\circ} \mathrm{C}$ to $8 \mathrm{mgL}^{-1}$ at $30^{\circ} \mathrm{C}$ i.e. ice-cold water can hold twice as much dissolved oxygen as warm water (Wetzel, 2001).

The COD measured in the present study was $5.4 \mathrm{mgL}^{-1}$ lower than the value reported by ENPHO, $2003\left(7 \mathrm{mgL}^{-1}\right)$ and Bhattrai et al, $2008\left(11 \mathrm{mgL}^{-1}\right.$ in December, 2008) for sundarijal reservoir. A lower COD level indicates that a smaller amount of oxidizable organic matter in the sample, which will reduce dissolved oxygen (DO) levels as well.

Biological oxygen demand (BOD) is one of the most common measures of organic material pollution in water. BOD indicates the amount of putrescible organic matter present in water. Therefore, a low BOD is an indicator of good quality water while a high BOD indicates polluted water. BOD measured in the study was $2.0 \mathrm{mgL}^{-1}$.

In the study, the concentration of iron and chromium were found to be $0.05 \mathrm{mgL}^{-1}$ and that of $\mathrm{Mn}, \mathrm{Pb}, \mathrm{Cu}$ were found to be less than $0.01 \mathrm{mgL}-1$ which is within the limit of NDWQS. However, the concentration of zinc was found to be $0.32 \mathrm{mgL}^{-1}$, slightly greater than the previous study.

The study reveals that the most of the parameters are within the limit of WHO and NDWQS level. But, the sample water is heavily contaminated with coliform bacteria. So, regular monitoring and supervision of the reservoir site is a prime importance for the concerned authorities and policy makers.

The visitors and trekkers using reservoir premises for picnic, recreation, cooking, bathing and washing were observed during our visit of sample collection. 


\section{Conclusion}

Although the surrounding environment of reservoir and its feeding streams are not managed properly, most of the physical and chemical parameters are within the limit of WHO and NDWQS standard. But the study reveals that there is a considerable contamination of coliform bacteria. Therefore, water is not safe to consume without intense treatment with disinfectants. The recent findings indicate that there are higher TC and FC counts in the sample than the previous record of the same reservoir. This draws attention towards further research. Therefore, recent demographic survey near the reservoir site and villages near the catchment areas need to be conducted.

\section{References}

[1] Adepoju-Bello, A. A., \& Alabi, O. M. (2005). Heavy metals: A review. The Nig. J. Pharm, 37, 41-45.

[2] Agrawal, S. C. (1999). Limnology. APH Publishing.

[3] American Water Works Association. (2013). Chromium in drinking water: a technical information primer.

[4] APHA (1992).Standard Methods for the examination of water and waste water, American Public Health Association., 18th edition.

[5] Ashish, B., Neeti, K., \& Himanshu, K. (2013). Copper toxicity: a comprehensive study. Research Journal of Recent Sciences ISSN, 2277, 2502.

[6] Badge,U.S. and Verma A.K.(1985).Limnological studies in J.N.U.lake.Bull.Boat.Soc.Sagar.

[7] Bakare-Odunola, M. T. (2005). Determination of some metallic impurities present in soft drinks marketed in Nigeria. The Nigerian Journal of Pharmaceutical Research, 4(1), 51-54.

[8] Beaumont, J. J., Sedman, R. M., Reynolds, S. D., Sherman, C. D., Li, L. H., Howd, R. A., ... \& Alexeeff, G. V. (2008). Cancer mortality in a Chinese population exposed to hexavalent chromium in drinking water. Epidemiology, 12-23.

[9] Bhattarai, K. R., Shrestha, B. B., \& Lekhak, H. D. (2008). water quality of Sundarijal reservoir and its feeding streams in Kathmandu. Scientific World, 6(6), 99-106.
[10] Copper, I. O. M. (2001). Dietary reference intakes for vitamin A vitamin $\mathrm{K}$, arsenic, boron, chromium, copper, iodine, iron, manganese, molybdenum, nickel, silicon, vanadium, and zinc (pp. 224-57). Washington, DC: The National Academies Press.

[11] Dobson, A. W., Erikson, K. M., \& Aschner, M. (2004). Manganese neurotoxicity Ann NY Acad Sci 1012: 115-128. Find this article online.

[12] Elinder CG. Zinc. In: Friberg L, Nordberg GF, Vouk VB, eds. Handbook on the toxicology of metals.

[13] ENPHO (1997).Monitoring and Assessment of water quality in the Shivapuri watershed. Environmental and Public Health Organization. 2nd ed. Amsterdam, Elsevier Science Publishers, 1986:664-679.

[14] Fine, J. S. (2000). Iron poisoning. Current problems in pediatrics, 30(3), 71-90.

[15] Gerber, G. B., Leonard, A., \& Hantson, P. H. (2002). Carcinogenicity, mutagenicity and teratogenicity of manganese compounds. Critical reviews in oncology/hematology, 42(1), 25-34.

[16] Gillies ME, Paulin HV 1982. Estimations of daily mineral intakes from drinking water. Human nutrition applied nutrition. Vol 36: 287-292.

[17] Goeringa, P. L., \& Barber, D. S. (2007). Hepatotoxicity of Copper. Iron, Cadmium, and Arsenic, Comprehensive Toxicology, 9, 501-526.

[18] Grazuleviciene, R., Nadisauskiene, R., Buinauskiene, J., \& Grazulevicius, T. (2009). Effects of Elevated Levels of Manganese and Iron in Drinking Water on Birth Outcomes. Polish Journal of Environmental Studies, 18(5).

[19] Hershko, C., Link, G., \& Cabantchik, I. (1998). Pathophysiology of Iron Overload a. Annals of the New York Academy of Sciences, 850(1), 191-201.

[20] International Organization for Standardization; ISO (1986). Water quality - determination of cobalt, nickel, copper,zinc, cadmium and lead-flame atomic absorption spectrometric methods.

[21] Jhigran V.G. (1975).Fish and Fishery of India. Hindustan Publishing Company.

[22] Kundangar, M. R. D., Sarwar, S. G., \& Hussain, J. (1996). Zooplankton population and nutrient dynamics of wetlands of Wular lake, Kashmir, India. Environment and biodiversity in the context of 
South Asia, 128-134.

[23] L.D.Chrosniak, L.N.Smith C.G., Mc Donald B F Jones, J.M.Flinn, 2006. Effects of enhanced zinc and copper in drinking water on spatial memory and fear conditioning. Vol 88: 91-94.

[24] McCord, J. M. (1998, January). Iron, free radicals, and oxidative injury. In Seminars in hematology (Vol. 35, No. 1, pp. 5-12).

[25] Mergler, D., Baldwin, M., Belanger, S., Larribe, F., Beuter, A., Bowler, R., \& Hudnell, K. (1999). Manganese neurotoxicity, a continuum of dysfunction: results from a community based study. Neurotoxicology, 20(2-3), 327-342.

[26] Mohod, C. V., \& Dhote, J. (2013). Review of heavy metals in drinking water and their effect on human health. International Journal of Innovative Research in Science, Engineering and Technology, 2(7), 29922996.

[27] Office of Environmental Health Hazard Assessment. (2010). "Draft Public Health Goal for Hexavalent Chromium". $\quad$ from http://oehha.ca.gov/water/phg/pdf/HexChromfacts $\underline{082009}$.

[28] Orosun, M. M., Tchokossa, P., Orosun, R. O., Akinyose, F. C., Ige, S. O., \& Oduh, V. O. (2016). Determination of selected heavy metals and human health risk assessment in fishes from Kiri Dam and River Gongola, Northeastern Nigeria. J. Phys. Chem. Biophys, 6(5), 1-6.

[29] Ryan, T. P., \& Aust, S. D. (1992). The role of iron in oxygen-mediated toxicities. Critical reviews in toxicology, 22(2), 119-141.

[30] Saravu, K., Jose, J., Bhat, M. N., Jimmy, B., \& Shastry, B. A. (2007). Acute ingestion of copper sulphate: A review on its clinical manifestations and management. Indian Journal of Critical Care Medicine, 11(2), 74.

[31] Shrestha, R. R., Rai, N. G., \& Shakya, S. K. (1996). Report on the water source monitoring program for the Shivapuri watershed by assessing water quality, June/July 1996 (1st Phase).

[32] Toxicological Profile for Manganese (2002).Agency for Toxic Substances and Disease Registry (ATSDR).Atlanta, GA.
[33] Water, H. D. Z. G. I. (2009). What Is Zinc?

[34] Wetzel, R.G. (1983).The Oxygen Content in freshwate, Limnology, M. Brown. p.172.

[35] WHO (1996).Guidelines for drinking water quality. World Health Organization.

[36] Wikipedia (2018). https://en.wikipedia.org/wiki/Nitrilotriacetic_acid.

[37] zur Wasser, D. E., \& Schlamm-Untersuchung, A. U.(1989). German standard procedures for testing water, wastewater and sludge. 